\title{
Reenacting Rape in Édouard Louis's History of Violence
}

\section{Introduction}

At the core of the French writer Édouard Louis's second novel Histoire de la violence (2016) is a traumatic episode experienced by the writer himself: a physical and sexual assault by a young man of Kabyle ${ }^{1}$ origin, named Reda, whom the writer met on his way home from a Christmas Eve dinner with his best friends Didier and Geoffroy. As Édouard ${ }^{2}$ crosses Place de la République in Paris by foot, a smiling young man starts following him. Struck by his beauty and attracted to his breath, Édouard gives up his initial impulse to ignore the stranger and the two men start a conversation. After a few minutes, Édouard ends up inviting Reda into his apartment and they make love repeatedly. As Reda gets ready to leave Édouard's apartment, Édouard realizes his telephone is missing. When he spots his iPad in Reda's jacket, he confronts him about his now missing phone. This unleashes Reda's uncontrolled anger and violence: Reda first strangles Édouard with a scarf, then threatens him with a gun, and finally rapes him before leaving the apartment at dawn.

Histoire de la violence is constructed as a fragmented, polymorphous, and polyphonic web of renditions of what happened from the moment Édouard left his friends on Christmas Eve to the night of 25 December, when the criminal police left his apartment after securing fingerprints and DNA evidence. Édouard's sister, Clara, recites in front of her mysteriously silent husband what Édouard told her about the fateful hours before, during, and after the rape. In a mesmerizing narrative mixing her own popular vernacular with standardized language, Clara gives direct and indirect quotes from her brother's narration. She also makes digressions in which she narrates episodes from Édouard's earlier life and comments on her brother's personality, decisions, gestures, and reactions.

1 The Kabyle are a Berber ethnic group from Northern Algeria, the second largest Berber-speaking population in Africa.

2 In Historie de la violence, Édouard Louis is the main character as well as the author. Given the complexity of voice in this novel, I primarily use "Édouard" to refer to the character in the book and "Louis" to refer to the author's literary persona. This distinction, however, is not absolute as the two roles blend into one another.

○ OpenAccess. () 2020 Adriana Margareta Dancus, published by De Gruyter. (cc))BY-NC-ND This work is licensed under the Creative Commons Attribution-NonCommercial-NoDerivatives 4.0 License. 
Louis's novel is, however, not simply Clara's narrative. Louis inscribes himself physically into the narrative as an attentive ear overhearing his sister's description of his own story from behind a door. As Clara recounts the story, Louis intervenes in the text, oftentimes in regular roman text, other times in italics, and occasionally in parenthesis. In his interventions, he corrects, elaborates, dismisses, and even attempts to silence his sister. He also delivers a short essay about Temple Drake's inability to flee from her rape scene in William Faulkner's novel Sanctuary. How can we understand this intriguing literary project that performs the author's own embodied experience of being raped by weaving together past and present in so many voices?

In this article, I argue that Histoire de la violence functions as a reenactment. In psychotherapy, reenactments are commonly seen as spontaneous, unintentional, involuntary, and compulsive behavioral phenomena whereby trauma survivors recreate and repetitively relive the past trauma in their present lives (Freud 1955 [1920], Freud 1958 [1914], Levy 1998). Even in those cases when trauma survivors actively engage in reenacting a pattern in the traumatic experience, psychotherapists warn that the active reenactment is more reflective of a maladaptive defensive strategy than an adaptive process (Levy 1998).

In film studies, we find a different definition of the reenactment. The reenactment is an established cinematic method in documentary and nonfictional media used to reconstruct prior events that have not been captured on camera. Starting with the 1980s, the reenactment has gained increased popularity in film, with directors including the Americans Errol Morris and Jill Godmilow, the German Werner Herzog, and the Danish Jon Bang Carlsen playing important roles in showing how the reenactment can be used to complicate and to question conventional understandings of genre, truth, authenticity, memory, and time, to name a few. Since the 2000s, a new generation of directors have continued to experiment with reenactment in a desire to push aesthetic, political, and ethical borders - for example, American Joshua Oppenheimer, whose 2012 documentary The Act of Killing generated heated debates about the what, who, how, where, and when of reenactment.

American film scholar Bill Nichols (2008) argues that reenactments in film are neither historical evidence nor explanations, but rather artistic interpretations with a "fantasmatic" power. Provocatively, Nichols turns to psychoanalysis to theoretically frame his discussion of cinematic reenactment. His starting point is the concept of fantasy, that imaginary engagement that occupied a central place in Freudian and Lacanian psychoanalysis. Referencing the work of the French psychoanalysts Jean Laplanche and Jean-Bertrand Pontalis on fantasy (fantasme in French), Nichols explains, "fantasy is not the mere retrieval of something past, not the recovery of a real object" (Nichols 2008: 76), but "the 
mise-en-scène of desire" in which "the subject becomes "caught up himself in the sequence of images”" (Laplanche and Pontalis, as quoted in Nichols 2008: 77). Likewise, Nichols continues, reenactments are fantasmatic experiences: they resurrect a past that enlists desires, losses, and longings, making the viewers become emotionally invested in the story (Nichols 2008: 74-78). Further, the filmmaker's perspective and voice is an inherent part of this interpretative process as images ultimately embody his or her fantasies (Nichols 2008: 78). As such, "reenactments are clearly $a$ view rather than the view from which the past yields up its truth" (Nichols 2008: 80, emphasis in the original). Although reenactments have a partial, constructed, and ritualistic quality, their fantasmatic power to vivify the past and render desire visible make them emotionally appealing and ultimately convincing.

I argue Nichol's definition of the cinematic reenactment is suited to capture what Louis does in Histoire de la violence when he sets out to go through the motions of his traumatic past. In his own and his sister's words, Louis is not merely reliving his trauma in an involuntary gesture, as psychotherapists have suggested. Rather, he conscientiously resurrects the ghosts of his rape and reanimates his traumatic past with the force of desire. I want to investigate the fantasmatic force that radiates through this novel and closely investigate how this carefully controlled and highly evocative reenactment functions. For what purpose does Louis reenact, and how does he structure the reenactment? In order to answer these questions, I will closely investigate the sequence of images in which Édouard Louis is caught up, which is at the core of the reenactment.

The novel is packed with media, artistic, and mental images. There are references to films, photographs, and paintings. There is an abundance of mental images such as memories, delusions, visions, hallucinations, nightmares, flashbacks, and foreshadowing. The visuality of these mental images is commonly underscored linguistically in the text when Louis writes that he sees pictures in his head. There are also innumerous ways of looking and being looked at: looking through, looking out, looking away, keeping an eye on someone, watching, scrutinizing, staring, gazing, catching a glimpse of, peeping, observing, peering, seeing oneself from outside, confronting or avoiding glances, overseeing, and not seeing at all.

Starting from three different topoi, the first outburst of violence, confiding rape in family and friends, and testifying in front of officials, I investigate the nature of these images and their ambiguous roles, equally traumatizing and healing, displacing and stabilizing. Moreover, I show how the boundaries between these various types of images are fluid. Assembled in a complex fashion reminiscent of the editing techniques available to a filmmaker, media and artistic images mobilize mental images, and vice versa. Finally, I demonstrate how Louis 
does not reanimate his personal trauma primarily to carry out the work of mourning and recover truth; instead, he resurrects the past in order to reclaim his story from the forensic, medical, and judicial discourse. He turns the tables not on the rapist, but on his friends, who pushed him to report the assault to the police, the medical staff, who objectified his personal trauma through the scientific gaze, and the police, who asked him to recount the traumatic episode innumerous times and who, in the end, archived his story in a racially charged fashion.

\section{The first outburst of violence}

The first manifestation of Reda's violence, which then culminates in the rape, is an attempt to strangle Édouard. The novel repeatedly comes back to the strangulation, in fact more so than the rape itself. If the involuntary penetration is described as an olfactory experience, a peach smell that emanates from Édouard's bed sheets, at the core of the strangulation episode are media as well as mental images. The reason Édouard is so preoccupied with his missing phone is because of digital photos he took on a vacation with his best friends Didier and Geoffroy, which are stored on the phone's memory. When Édouard insists on getting his phone back, Reda becomes unexpectedly violent and strangles Édouard with a scarf. In other words, digital images (photographs) of mental images (vacation memories) indirectly trigger a violence not anticipated by Édouard.

Moreover, the fifty seconds during which Reda is strangling Édouard are repeatedly rendered in Clara's as well as Édouard's words as an out-of-body visual experience. In chapter 4, Édouard describes in retrospect how he testified at the police station for the first time. Unable to give a structured testimony during the first meeting with the police, Louis goes through the motions of the strangulation from a fly-on-the-wall perspective. He likens himself to an earthworm that squirms, twists, and turns under a shoe (Louis 2018: 41). He also remembers how the policeman watched him talk: "He wasn't listening, he was watching" (Louis 2018: 41). ${ }^{3}$ The policeman's way of watching Édouard is debilitating in two respects. First, it is indicative of the police's power to either drag the interrogation out or to immediately end it (Louis 2018: 42). Second, it is also a condemnation of Édouard's behavior when he decided to bring a stranger up to his apartment in the middle of the night (Louis 2018: 41-42).

3 “Il n'écoutais pas, il regardait parler” (Louis 2016: 55). 
In chapter 8, when Clara suggests that Édouard failed to understand that he was actually being strangled, Louis corrects her in an italicized parenthesis that echoes the cinematic voiceover. The choice of punctuation and graphics visually underscores the temporal distance between the past and the reenactment, as well as the difference between Clara's and Édouard's point of view. Once Reda started to strangle Édouard with a scarf, "nothing passed before my eyes, no reflection, no memory," only a concrete image: a close-up of Édouard's own hands gripping the scarf "out of a purely reflexive resistance to dying” (Louis 2018: 110). ${ }^{4}$ Here, the strangulation is no longer visualized through a pictorial metaphor from above (like an earthworm under the shoe). In the same italicized parenthesis, Édouard explains how he lost his ability to think, reflect, and remember in that perilous moment. As Reda attacked him, the only thing he had left was the fear of death, which then materialized into a weak gesture of physical resistance (his hands gripping the scarf). He had lost language and, allegedly, his humanity. He was no longer like a worm. He had become the worm.

In the same chapter, this visualization incites a new set of images, which are assembled in a very cinematic fashion. First, there are media images that crosscut the close-up of his hands gripping the scarf:

I'd thought the imminence of death would have doubled my strength and my courage, would have revealed a power, an ability to shout, to fight, to escape, to run, to defend myself, that even I had never suspected. Of course, in the movies, in newspapers and magazines, I'd seen characters capitulate in their own deaths, and surrender, but I thought I was different, and these images always filled me with a wave of disgust and contempt as I watched them give up the fight so quickly. I thought: I'm much stronger than they are. (Louis 2018: 118-119)

Balancing on a thin thread between life and death, Édouard is unable to fight back and instead surrenders to violence, just like the characters he has seen in movies, newspapers, and magazines.

Second, another mental image, a memory, cuts across the close-up of the strangulation. Writing in regular roman text, Louis now confesses that he kept

4 “[...] je ne voyais rien défiler sous mes yeux, ni réflexion, ni souvenir [...] c'était un refus purement physique de la mort" (Louis 2016: 130).

5 “[...] j'étais persuadé que l'imminence de ma mort m'aurait permis de décupler ma force et mon courage, m'aurait fait découvrir une puissance, une capacité à crier, à lutter, à fuir, à courir, à me débattre, que je n'aurais jamais pu soupçonner auparavant, bien sûr, j'avais vu au cinéma, dans les journaux ou dans la littérature des personnages capituler devant la mort, se rendre, mais je m'estimais différent d'eux, et chaque fois ces images m'emplissaient d'une vague de dégoût et de mépris en les voyant abandonner la partie si vite. Je pensais: Je suis beaucoup plus fort qu'eux" (Louis 2016: 140). 
this memory hidden from everyone he had talked to, "not for reasons having to do with memory or the need to forget certain things, but simply out of shame" (Louis 2016: 120). ${ }^{6}$ Hoping to recover his phone, Édouard asked Reda to help him look for it in his apartment. He also suggested a compensation of 50 euros for whoever found the phone first. After a superficial attempt to look after Édouard's phone, Reda burst into a rage and attacked him. Louis recalls this imprudent play "better than the rest of night; these are the images that remain most vivid and robust [...] as if Didier is right and the things we remember most clearly are always those that bring us shame" (Louis 2018: 120). ${ }^{7}$

A fantasmatic power lies in these repeated visualizations, which show the strangulation from various perspectives and in various types of shots that frame Édouard from above or in a close-up. Louis goes through the motions of his inability to resist through the dispersed and polymorphous voices of Édouard, Clara, and himself. Through the reenactment, we see him disqualify his initial contempt and disgust at capitulating in the face of death. Instead, he ends up accepting the work of shame, for he was not simply a passive victim, but, in fact, an instigator of his own misfortune.

\section{Confiding rape to family and friends}

Didier and Geoffroy are Édouard's best friends and confidants. After breaking the bond with his biological family, they also function as a substitute family for him. They accept who he is, including his sexual orientation, and give him the intellectual stimulation he has always lacked from his working class family. In chapter 13, Louis renders in his own words, in regular roman text, how he remembers sharing his rape experience with his friends the day after he met Reda. He also includes paragraphs in italics in which he reveals his unspoken thoughts during the confession. As in the case of the strangulation, Louis is caught up in a sequence of images with a fantasmatic power. Let us take a close look at these images as well as the various ways of looking and being looked at.

Chapter 13 opens with Édouard arriving at a café, Le Sélect, and watching Didier from a distance. Didier is wearing the sweater Édouard gave him as a Christmas present the day before. He looks distressed. Didier's distress makes

6 “[...] non pas pour des raisons qui concernent la mémoire et les oublis qui en sont la condition, mais tout simplement à cause de la honte” (Louis 2016: 141-142).

7 “[...] même beaucoup mieux que du reste de la nuit, ce sont les images que je garde les plus vivantes et les plus épaisses [...] à croire, comme le soutient Didier, que les plus vifs souvenirs d'une vie sont toujours ceux de la honte" (Louis 2016: 142). 
Édouard think immediately of how his sister Clara looked at him when they watched a documentary together on the French TV channel TV5: "when the voice-over said the word rape I could feel Clara's embarrassment, I saw her mouth tighten, her eyes narrow, and I hated it, I hated her distress, the way it forced me back into the past" (Louis 2018: 155). ${ }^{8}$ In front of the TV, Édouard experiences Clara's distressed way of looking at him as a violation, a reminder of the rape, but also a mistreatment: "I thought: She will never understand that, as much as I cling to my story, it is also the thing that seems furthest from me and the most foreign to what I am" (Louis 2018: 155). ${ }^{9}$ Clara's inability to understand Édouard foreshadows what will happen in the critical moments Édouard tells his friends about the rape.

Didier advises Édouard to talk, which Louis interprets as an invitation not to forget; more so, an obligation to remember the past without repeating it. This, Louis explains, is possible through a visual engagement with the images of rape, which in turn will allow Édouard Louis to detach himself from his own trauma: "the more I remember and the more I lose myself in the images that remain, the less they have do with me" (Louis 2018: 156). ${ }^{10}$ This process of distancing is, however, interrupted when Didier suddenly asks Édouard to report the rape to the police. Édouard is unwilling to do so, and instead anchors his gaze on his friend's sweater in an attempt to take control of the images and the situation. But Didier continues his plea, as does Geoffroy, who joins them at the café later.

When the fleeing of the gaze no longer works as a strategy to suspend his friends' insistence, Édouard seeks refuge in a mental image: a memory of a prison visit Édouard paid to his cousin Sylvain when he was younger. Through a flashback, Édouard transports himself into a past his friends cannot see, neither concretely, because Édouard keeps the memory to himself, nor figuratively, because the vision from prison is simply too foreign for Didier and Geoffroy: “they've never seen the prison gate [...] they haven't seen the brick wall, they haven't seen the shadow of the wall, they haven't seen the families lined up before the wall, begging and grovelling, waiting for the guard to call their name, waiting

8 "Quand la voix off a dit le mot viol, j'ai senti la gêne de Clara, j'ai vu sa bouche se rider, ses yeux se plisser, et j'ai haï cet embarras, j'ai haï cette désolation que me faisait entrer de force dans mon passé" (Louis 2016: 184).

9 "[...] je pensais: Elle ne pourra jamais comprendre que mon histoire est à la fois ce à quoi je tiens le plus et ce qui me paraît le plus éloigné et le plus étranger à ce que je suis" (Louis 2016: 184).

10 "[...je cherche à construire une mémoire] par laquelle plus je me souviens et plus je me dissous dans les images qu'il me reste, moins j'en suis le centre” (Louis 2016: 185). 
to file inside" (Louis 2018: 157-158). ${ }^{11}$ The emotional distance between Édouard and his friends is thus framed as an inability to see, underscored linguistically through the repetition of "they haven't seen."

Haunted by the vision from prison, yet unwilling to share this memory with his friends, Édouard invokes instead his fear of the rapist's revenge as a reason not to report him. Didier quickly dismisses this fear as unfounded, which makes Édouard furious. In italicized text, Louis explains how he saw his friends become extensions of Reda and how he experienced their insistence, dismissal, and inability to understand him as acts of aggression: "They are Reda, they are Reda [...] You're begging them to stop but they won't, they're strangling you, they're suffocating you and no matter how you beg them to stop, they won't" (Louis 2018: 160). ${ }^{12}$ By pushing their friend to report the rape, Didier and Geoffroy come to incarnate a form of violence that Édouard cannot fight back, just as it happened during the strangulation. Although Édouard thinks it is the victim's right to choose not to report what has happened, he cannot put forward this argument in front of his friends, and instead looks down in shame (Louis 2018: 161).

Here as well, Édouard feels shame, but this time, not on his own behalf, as was the case when he remembered how he asked Reda to look for his phone, instead responding to Didier's and Geoffroy's shamelessness. This new shame does not cut through his flesh as a vivid memory. Instead, it is experienced once again as a disembodiment: "At the end of the meal, we paid and walked towards the police station, but my body was not my own, I watched it lead me there" (Louis 2018: 162). ${ }^{13}$ Instead of achieving control by distancing himself from the images of violence, Édouard feels violently pushed back to the center of his personal trauma when he confides in his friends.

Chapter 13 is not simply a reiteration of Édouard's submission to his friends' requests, a compulsive going through the motions of his inability to counter their insistence with good arguments. His silence at the time is replaced in the novel by a dialogical discourse between Édouard Louis's several voices, heard and un-

11 “[...] eux n'ont pas vu l'entrée de la prison [...] ils n'ont pas vu le mur de briques, eux n'ont rien $v u$, ils n'ont pas vu les familles devant le mur, ils n'ont pas vu devant le mur les familles suppliantes rampantes attendant que leur nom soit prononcé, attendant de pouvoir entrer au parloir" (Louis 2016: 187).

12 "[...] Ils sont Reda, ils sont Reda [...] tu les supplies d'arrêter mais ils n'arrêtent pas, ils t'étranglent, ils t'étouffent et tu les supplies de s'arrêter mais ils ne s'arrêtent pas. Ils ne s'arrêtent pas." (Louis 2016: 189)

13 "À la fin du repas, nous avons payé et nous avons marché en direction du commissariat, mon corps n'était pas le mien, je le regardais m’emmener au commisariat.” (Louis 2016: 191) 
heard, past and present. Graphically marked by the use of regular roman text and italics, these parallel narratives double up to reanimate Édouard's present inner struggle with the force of desire. The fantasmatic power emerges as an effect of this polyphony and intensifies the novel's emotional appeal to sympathize with the rape victim's need to keep silent. Through the reenactment, Édouard's desire not to report his rapist is finally made visible.

\section{Testifying in front of officials}

By making Édouard report the rape to the police, Didier and Geoffroy expose their friend to institutional violence that only exacerbates his personal trauma. During the repeated testimonies Édouard gives in front of different police and medical units, he experiences a sense of humiliation and powerlessness. Photographs taken by officials are instrumental in Édouard's experience.

An evocative scene illustrating the officials' insensitive and even violating use of photographs occurs at Urgences medico-judiciaire (UMJ), a medical unit attached to the legal system in France where abuse victims are consulted by a team of experts. In order to issue a medical certificate with judicial leverage, a doctor and a nurse document the assault on Édouard's body by measuring, palpating, and photographing his bruises. In chapter 15, the consultation is narrated in past tense from a third person perspective. Completely absorbed in the process of securing visual documentation, the doctor "talked to himself, for himself: 'I'm going to take one with the flash off, there we go, that's better ... and one more"” (Louis 2018: 176). ${ }^{14}$ Through the lens of the camera, the doctor's scientific gaze objectifies Édouard's body to his visible bruises, an objectification amplified by the next step in the consultation. For the doctor subsequently asks Édouard to take off all of his clothes as both he and the nurse "were both watching and waiting, with no pretence of looking away" (Louis 2018: 177) ${ }^{15}$ Just as during the interrogation at the police station, when the policeman was watching rather than listening to Édouard give a testimony, the way in which the medical officials are now watching is also debilitating. First, Édouard is reminded of how embarrassed he used to be by his own naked body during check-ups and class trips to the pool in primary school, then he is shocked when he is asked to sit on all fours on the consultation table so that the doctor can push a spatula inside

14 “[...] il parlait avec lui-même, pour lui-même, 'Je vais en faire une sans flash, voilà, c'est mieux comme ça, encore une"” (Louis 2016: 205).

15 "Le médecin et l'infirmière étaient tournés vers moi, ils me fixaient, sans faire semblant de ne pas regarder mon corps” (Louis 2016: 206). 
his anus and take more photographs: "They're photographing the inside of my body. I heard the little click of the camera every time they took a picture, and the doctor murmuring to the nurse, lesions, haematomas" (Louis 2018: 177). ${ }^{16}$

In front of the doctor, Édouard camouflages his embarrassment and shock by poking fun at his heavy bleedings after the rape: "I said: 'If anyone wanted to find me, they could just follow my trail"' (Louis 2018: 177). ${ }^{17}$ If the images from the strangulation scene and the conversation with Didier and Geoffroy fill Édouard with shame, the scene of the consultation leaves Édouard with "a taste of self-loathing"18 in his mouth caused by his desperate attempts not to act as a traumatized person (Louis 2018: 178).

Why does Louis choose to go through the motions of this invasive and humiliating experience triggered by the medical staff's visual documentation of the rape? I suggest Louis reanimates his humiliation in an attempt to fight back the officials, this time with his own images.

This is particularly evident if we look closer at how, on several occasions, Louis superimposes personal memories with images from the encounter with Reda. The French film critic André Bazin (1946) notes that superimpositions were commonly used in the silent film era to suggest the fantastic, as in dreams, hallucinations, or imaginary characters such as ghosts. In Histoire de la violence, Louis uses superimpositions (i.e., the placement of one image on top of an existing one) to bring fantasmatic gratification to the present.

Early in the book, in chapter 2, Édouard recalls how he, after repeated testimonies in front of the police and the medical personnel, had no more tears to give when narrating his assault in front of the UMJ team. He is terrified by his inability to cry, as he fears this will undermine his credibility. In an attempt to control the situation, he draws from his memory images of Reda's face and gun, but his eyes do not moisten (Louis 2018: 26). When the traumatic images from his recent past fail to do the expected affective work, Édouard adds to them some of the saddest and most painful memories from his past. He remembers how Geoffroy gave him the news of the death of his friend, Dimitri, a death Édouard envisioned even before it was confirmed: "I was trying not to think of his body laid out in a stretcher - it was the first thought I had" (Louis 2018: 27). ${ }^{19}$ Too distant to make him cry, this older, painful memory of his friend's death de-

16 "Ils photographient l'intérieur de mon corps, j'entendais le petit clic de l'appareil photo a chaque capture, et le médecin qui murmurait à l'infirmière, lésions, hématomes” (Louis 2016: 207). 17 "J'ai dit: 'On pourrait me suivre à la trace”" (Louis 2016: 207).

18 “[...] un gout de mépris de moi-même” (Louis 2016: 207).

19 “[...] j’essayais de m'empêcher de penser à son corps étendu sur une civière, l'image était tout de suite apparue [...]” (Louis 2016: 39). 
nies Édouard fantasmatic gratification at the moment of the consultation. In retrospect, his inability to cry gives Louis a sense of victory precisely because his superimposed memories refuse to perform the affective work commonly expected from a rape victim. Ultimately, as Louis notes to the reader in italics, once the doctor at the UMJ rounds up his consultation, "[t]here was no need for tears, my body was enough" (Louis 2018: 176). ${ }^{20}$

On other occasions, Louis superimposes personal memories with Reda's own memories, as he envisions them based on snippets of conversation preceding the assault. In chapter 5, when Reda tells him about his father's experience as a newly arrived immigrant in a French asylum center, Édouard superimposes images of the center's manager with images of an outcast from his local community: "it was images of Ordive that flashed into my mind; [...] and so while I listened to Reda, I thought of Ordive, a woman I hadn't seen in ten years, convinced that this manager looked like her" (Louis 2018: 56-57). ${ }^{21}$ As a young adult, Édouard feels compassion for Ordive, but as a child, he knew no better but to hate and deride her, much like everyone else in his community. When Reda describes the manager as widely despised by the asylum seekers, Édouard immediately buys into this image. In retrospect, however, he sees himself as being manipulated by Reda. He corrects this manipulation by superimposing shameful memories of Ordive's bullying with the manager's public condemnation.

Further, in chapter 6, Édouard tells Didier and Geoffroy a story in which he superimposes images of Reda with images of his cousin Sylvain during an episode in school when Sylvain allegedly tried to jump out of the classroom window. To make clear how the superimposition occurs in the text and how Édouard's images of Reda and Sylvain flash onto each other, a lengthier citation from the novel is required:

I imagine a classroom awash with light. [...] Everyone was quiet when Reda stood and walked over towards the windows. [...] He opens the sash and swings one leg out of the window. It was my cousin Sylvain who did this. [...] It wouldn't be my cousin, in this version, but Reda. I'm transposing. [...] At the same time that the teacher, who had been sitting there as silent and astonished as everyone else, realises what's going on and cries out, Reda cries out too - that's what my cousin did, according to the story I heard and repeated, in turn, many times - [...], I say to Didier and Geoffroy, it's like a tableau with the teacher on the right - hands clasped before her mouth, as well they might be, eyes wide, the only possible response a body can make at the moment of such complete impotence - and Reda on

20 “Les pleurs n'étaient pas nécessaires, mon corps suffit." (Louis 2016: 206)

21 “[...] les images d'Ordive me sont venues à la tête [...] et j'ai donc pensé à Ordive pendant que j'écoutais Reda, cette femme que j'ai vue pour la dernière fois il y a une dizaine d'années, et j'étais sûr que le directeur du foyer du père de Reda lui ressemblait” (Louis 2016: 71). 
the left, the two of them almost perfectly symmetrical, [...] He didn't have anything against the teacher in particular, he just wanted to see her transformed, deformed, transfigured by panic, he wanted to make the other kids laugh, he wanted to show who he was, to embody absolute freedom - Reda or Sylvain, it doesn't matter which - he wanted to be the image of freedom at its most spectacular. (Louis 2018: 79-81)22

Paradoxically, through his own family stories, Louis makes Reda's violence relatable and familiar. As Louis lets Reda take Sylvain's place in his memory, his cousin, just like Ordive, continues to haunt the text as a ghost of sorts in a tableau that Louis compares to an artistic image (a painting). Through the superimposition, Louis builds an emotional bridge between himself and the rapist and takes control of Reda's story. A fantasmatic gratification emerges as the author fabricates a story for his rapist, a story with which he can paradoxically identify.

In addition to superimpositions, Louis visualizes his own illusory mental images in order to highlight the social and institutional dimension of Édouard's personal trauma. In particular, he is interested in the violence embedded in the social and institutional contexts of which the rape victim is part. These visualizations take the form not only of grotesque distortions, nightmares, hallucinations, but also of liberating delusions, as when Édouard suddenly fantasizes about running away from the police station in the middle of his testimony: "I saw myself get up, splinter the door with my shoulder, run down the hallway to the street, and out into the night, and keep running. But there I was, still sitting in the chair" (Louis 2018: 164). ${ }^{23}$ These illusory mental images haunt the text

22 "J'imagine une salle de classe baignée par la lumière du jour [...] ils étaient silencieux quand Reda s'était levé et q'il avait marché jusqu' à une fenêtre [...] Il fait coulisser la vitre et il enjambe la fenêtre. C'est mon cousin Sylvain qui a fait ça [...] Ce ne serait pas mon cousin dans cette situation mais ce serait Reda. Je transpose. [...] En même temps que l'enseignante, qui d'abord est restée muette et étonnée comme les autres, comprend, et qu'elle pousse un cri, Reda en pousse un, c'est ce qu'avait fait mon cousin selon ce qu'on m'avait raconté et que j'avais souvent raconté à mon tour [...] j'avais dit à Didier et Geoffroy, c'est comme un tableau où elle est debout à droite du cadre, évidemment les mains jointes devant la bouche et les yeux grands ouverts comme cela doit se passer dans cette configuration, quand un corps repond à une situation, impuissante, et à gauche du cadre Reda, tous les deux presque symétriques [...] Il n'avait aucun conflit particulier avec l'enseignante, il voulait juste voir la panique la transformer, la déformer, la défigurer, il voulait faire rire les autres, prouver qui il était, il voulait incarner l'autonomie absolue - Reda ou Sylvain peu importe - la figure la plus spectaculaire de l'autonomie" (Louis 2016: $96-98)$.

23 "Je me suis vu me lever, ouvrir la porte d'un coup d'épaule et la faire voler en éclats, et courir dans le couloir, m'enfoncer dans la rue, dans la nuit, et courir encore. Mais j'étais toujours en place sur la chaise [...]” (Louis 2016: 193). 
with a fantasmatic power that pursues ideological issues such as medical negligence and police racism, and which I would now like to investigate.

A couple of hours after Reda leaves his apartment, Édouard heads to the emergency room of Saint Louis Hospital where he hopes to receive anti-HIV medication. After sharing his story, first with the receptionist and, twenty minutes later, with a nurse, Édouard is asked to wait for the doctor. It takes more than an hour to see the doctor, an excruciating delay especially when Édouard realizes the doctor was occupied with playing solitaire on her computer (Louis 2018: 140 -141). The only other person in the waiting room at the hospital is a homeless man who is seeking refuge from the winter cold and whose appearance disturbs Édouard. Édouard has a grotesque vision of the homeless man "biting into a piece of raw meat, the blood on his chin and lips," which, in turn, unleashes a premonition of his own death due to medical negligence: "In my impatience, I tightened my jaws and my fists, I thought: Now it's too late, you're sick, you're sick because of them, I got up and started walking around the room in circles again" (Louis 2018: 140). ${ }^{24}$

Made to wait in the corridors of Saint Louis Hospital, Édouard eventually sees himself dead and buried. He has a "horrid vision" of how Didier and Geoffroy embark on a trip from Paris to find their friend's grave, a nightmare Louis narrates in its entirety in chapter 11. Suggestively entitled "(details of a nightmare)," chapter 11 is presented as a parenthesis to Clara's rendition of her brother's story, a nightmare Louis explains he has never shared with his sister. Dreading the legal definition of dependents by which hospitals normally operate, Édouard tells the doctor at Saint Louis Hospital about his nightmare. In this way, he hopes to address a final medical neglect: that the hospital will inform only his biological family about his death, and not his friends, whom he sees as his real family.

In addition to grotesque distortions and nightmares, Édouard also has paranoid hallucinations fed by racism. Already in chapter 1, as Édouard recollects describing Reda's "soft yet rugged, masculine" features to his friend Henri (Louis 2018: 13), he points out the racism implicit in the terminology used by the police when referring to Reda as an "Arab male” in their report: “[...] I can still hear the racism of the police who interviewed me later, on that 25 December, I can hear the compulsive racism [...] because for them Arab didn't refer to some-

24 "Je m'impatientais, je serrais les poings et la mâchoire, je pensais: Maintenant c'est trop tard, tu es malade, tu es malade à cause d'eux, je me levais et je recommençais à marcher en rond, à faire des cercles dans la piece [...]" (Louis 2016: 167). 
body's geographical origins, it meant scum, criminal, thug" (Louis 2018: 14). ${ }^{25}$ Towards the end of the novel, in chapter 15, this institutional racism rubs off on Édouard: "I had become racist. Suddenly I was full of racism" (Louis 2018: 186). ${ }^{26}$ Édouard describes this experience as an estrangement from his true self, a disembodiment of sorts: "A second person took over my body; he thought for me, he spoke for me, he trembled for me, he was afraid for me, he inflicted his fear on me, he made me tremble over terrors of his own" (Louis 2018: 186187). ${ }^{27}$ Edouard starts fearing all the black, Arab, or potentially Kabyle men he encounters in public spaces and whom he avoids either by looking down or by looking away in a desperate attempt to protect himself. But Édouard is not only consumed by fear. He also rises above it by recognizing its prejudiced, stereotypical, and discriminatory nature. This augments his personal trauma: "I was traumatized twice over: by fear and by my fear" (Louis 2018: 187). ${ }^{28}$

His racial paranoia culminates in a hallucination Édouard has while visiting Istanbul with a friend. While sitting in a taxi on their way from the airport to the hotel, Édouard imagines that the taxi driver shot him dead with "a gun that looked like Reda's” (Louis 2018: 189). The reanimation of this unnerving hallucination is not simply an illustration of the psychic force of racism. More importantly, it allows Louis to take control of his fear at the time by going through the motions of his racist imaginary. Through the reenactment, Louis can re-inhabit that which racism has disembodied.

\section{Conclusion}

In Histoire de la violence, Louis uses a plethora of mental, media, and artistic images to orchestrate a reenactment of his own rape. At times, the images have a healing and stabilizing function, as when Édouard constructs a background for his rapist. At other times, they are traumatizing and displacing, as when he watches a documentary together with his sister Clara or when he has a grotesque vision of the homeless man he meets at the hospital. Yet in some other situa-

25 “[...] parce que j’y entends encore le racisme de la police pendant l'interrogatoire qui a suivi le 25 décembre, ce racisme compulsive [...] puisque pour eux type maghrébin n'indiquait pas une origine géographique mais voulait dire racaille, voyou, délinquant” (Louis 2016: 23).

26 "J'étais devenu raciste. Le racisme [...] me remplissait soudain [...]" (Louis 2016: 217).

27 "Une deuxieme personne s'était installé dans mon corps; elle pensait à ma place, elle parlait à ma place, elle tremblait à ma place, elle avait peur pour moi, elle s'imposait sa peur, elle m'imposait de trembler de ses tremblements" (Louis 2016: 217).

28 "J'étais traumatisé deux fois: de la peur et de ma peur" (Louis 2016: 217). 
tions, images can be traumatizing and healing at the same time, as when Édouard's paranoia unleashes a hallucination in the taxi in Istanbul, a frightening experience that paradoxically allows Louis to take control of his fear of the ethnic Other.

The novel also demonstrates how the boundaries between various types of images are fluid when reenacted. Photographs taken by the doctor at the UMJ make Édouard think back to unpleasant childhood memories when he was asked to display his nudity in public, while a narrated memory of his cousin defying his teacher is visualized as an artistic image, a painting framing the teacher and Reda in almost perfect symmetry. Cinematic transition techniques such as cross-cuts, foreshadows, flashbacks, superimpositions, and abrupt cuts are used to assemble the sequence of images. At times, images are sewn together in a seamless manner, as when Louis cross-cuts from Édouard filing a report with the police to an image from above of Édouard twisting and turning as Reda was strangling him. Most prominent, however, are the disjunctions in time, voice, perspective, and space through which the night with Reda is reenacted.

Through the reenactment, Louis reanimates his personal trauma with the force of desire in an attempt to reclaim his story from his friends and the officials (police and medical personnel), all of whom betrayed him. He chooses Clara as an invested, yet unreliable, narrator, in addition to himself, in order to underscore the partial and constructed nature of his reenactment and to inscribe ambiguity of voice and perspective.

As an aesthetic experiment, Histoire de la violence enthralls its reader with a fantasmatic force. We are mesmerized by and invested in Louis's narrative. As a political project, the novel puts societal violence at its center, as the generic title of the novel so well suggests. Reda is only one of the many faces violence can take. Violence also permeates through Didier and Geoffroy as well as through the doctors, nurses, policemen and policewomen Édouard meets through his testimony. Édouard's biological family, his sister and his local community are also instantiations of that violence, and, ultimately, so is Louis himself when he gives Reda a past he cannot dismiss.

As a matter of fact, in the aftermath of the publication of Histoire de la violence in France, Louis was brought to court for the way in which he depicted the rapist in his novel. Four days after the release of the book, the police arrested a man by the name Riahd B. whose DNA profiling matched the DNA evidence collected from Louis's apartment, but who denied having threatened Louis with a gun or having abused him sexually (Le Bailly 2016). Instead, Riahd B. pressed charges against Louis and his publisher for an attack on the presumption of innocence and for invasion of privacy (Le Bailly 2016, Meisingset 2016). The court 
dismissed the plaintiff's allegation on the account that Louis's description of Reda was generic and applicable to a large number of individuals, and therefore "insufficiently characteristic" (franceinfo: culture 2016). The turmoil, however, did not stop with the court's decision. The former radical Islamist Omar Benlaala pledged to give Reda a voice by writing a novel from the rapist's perspective (Meisingset 2016). This illustrates how violence is inscribed not only in the judicial, medical, and forensic discourse, as Louis so well exposed by writing Histoire de la violence, but also in the literary text. It seems as if there is no way to escape violence, perhaps only in a temporal fold afforded by the reenactment, which fills the reader not with disgust, anger, or guilt, but with a burning shame.

\section{Works cited}

Le Bailly, David (2016) "EXCLUSIF. Pourquoi Édouard Louis se trouve pris dans une tourmente judiciaire,” Bibliobs, 18 March <https://bibliobs.nouvelobs.com/actualites/20160309. OBS6054/exclusif-pourquoi-edouard-louis-se-trouve-pris-dans-une-tourmente-judiciaire. html> (accessed 11 February 2019)

Bazin, André (2012 [1946]) “The Life and Death of Superimpositions," Film-Philosophy, 6.1, <http://www.film-philosophy.com/vol6-2002/n1bazin〉 (accessed 11 February 2019)

Franceinfo: culture (2016) “'Histoire de la violence': l'agresseur présumé d’Édouard Louis débouté.” 15 April <https://www.francetvinfo.fr/culture/livres/roman/histoire-de-la-vio lence-l-agresseur-presume-d-edouard-louis-deboute_3278765.html> (accessed 11 February 2019)

Freud, Sigmund (1958 [1914]) "Remembering, Repeating and Working-Through

(Further Recommendations on the Technique of Psycho-Analysis II)," in James Strachey (ed.), The Standard Edition of the Complete Psychological Works of Sigmund Freud, Vol. 12 (London: Hogarth Press and the Institute of Psychoanalysis), pp. 146-156

Freud, Sigmund (1955 [1920]) “Beyond the Pleasure Principle," in James Strachey (ed.), The Standard Edition of the Complete Psychological Works of Sigmund Freud, Vol. 18 (London: Hogarth Press and the Institute of Psychoanalysis), pp. 1-64

Levy, Michael S. (1998) "A Helpful Way to Conceptualize and Understand Reenactments," The Journal of Psychotherapy Practice and Research, 7.3, pp. 227-235

Louis, Édouard (2018) History of Violence. Translated by Lorin Stein (London: Harvill Secker) Louis, Édouard (2016) Histoire de la violence (Paris: Éditions du Seuil)

Meisingset, Kristian (2016) "Kjærlighetsbrev, aborter og et barbert underliv: i hele Europa diskuteres grensene for hvor mye romanforfattere kan utlevere virkelige mennesker," Aftenposten, 8 October, pp. 2-3

Nichols, Bill (2008) "Documentary Reenactment and the Fantasmatic Subject," Critical Inquiry, 35.1, pp. $72-89$

The Act of Killing (2012) Dir. Joshua Oppenheimer (Final Cut for Real, Piraya Film A/S, Novaya Zemlya) 